\title{
FIELD PERFORMANCE OF COWPEA GENOTYPES GROWN UNDER VIRUS PRESSURE IN PUERTO RICO
}

\author{
R. GOENAGA, A.G. GILLASPIE ${ }^{1}$ and A. QUILES \\ USDA-ARS, Tropical Agriculture Research Station, 2200 P.A. Campos Ave., Ste. 201, \\ Mayaguez, PR 00680-5470 \\ ${ }^{1}$ USDA-ARS, Plant Genetic Resource Conservation Unit, 1109 Experiment Street, Griffin, GA 30223 \\ Corresponding author: Ricardo.Goenaga@ars.usda.gov
}

(Received 2 September, 2010; accepted 26 February, 2011)

\begin{abstract}
Cowpea [Vigna unguiculata (L.) Walp] is an important grain legume in many regions of the tropics. However, viral diseases, particularly Cucumber mosaic virus (CMV) and Blackeye cowpea mosaic virus (BICMV), can be a limiting factor in cowpea production. We evaluated under virus pressure the performance of four PI's (441917, $441919,612607,180014$ ) and a commercial cultivar (Coronet), in Puerto Rico during 2007-2008. Viral infection of plants with BlCMV and CMV in these experiments occurred naturally through insect vectors from mechanically inoculated spreader-row plants, as determined by direct antigen-coated enzyme-linked immunosorbent assay (DACELISA). PI441917 had the highest grain yield $\left(3682.8 \mathrm{~kg} \mathrm{ha}^{-1}\right)$ among all genotypes except for the virus resistant control PI 612607, which was not significantly different. PI's 180014 and 612607 had the highest seed protein concentration. The cultivar Coronet attained midbloom and maturity earlier than the other genotypes. These results confirm previous studies which showed that PI 441917 is an excellent yielder when plants are grown under virus pressure. This accession should be useful in cowpea breeding programmes to help control yield loses by CMV and BlCMV.
\end{abstract}

Key Words: Blackeye cowpea mosaic virus, Vigna unguiculata

\section{RÉSUMÉ}

La cornille [Vigna unguiculata (L.) Walp] est un important grain des légumineuses trouvé dans beaucoup de régions tropicales. Par ailleurs, les maladies virales particulièrement le virus de la mosaiqque du concombre (CMV) et le virus de la mosaïque de la cornillle Blackeye (BlCMV), peuvent être un facteur limitant de la production de la cornille. Nous avons évalué sous pression virale les performances de quatre PI $(441917,441919,612607$, et 180014) et un cultivar commercial (Coronet), à Puerto Rico au cours des années 2007-2008. L'infection virale des plants avec B1CMV et CMV dans ces essais a eu lieu naturellement à travers les vecteurs d'insects par le "spreadrow" méchanique des plantes, comme déterminé par l'enzyme-associé immunosorbant d'essai antigène enrobé (DAC-ELISA). PI441917 avait le rendement en grain le plus élevé (3682.8 $\mathrm{kg} \mathrm{ha}^{-1}$ ) parmi tous les génotypes, excepté pour le virus témoins résistant PI 612607, qui n'était pas significativement différent. PI 180014 et 612607 avient une concentration élevée en protéines. Le cultivar Coronet avait atteint la mi-floraison et la maturité plus tôt que d'autres génotypes. Ces résultats confirment ceux des études antérieures par lesquelles PI 441917 est un excellent produit lorsque les plants croissent sous pression virale. Cette accession pourrait être utile dans des programmes d'amélioration de la cornille pour aider à contrôler les pertes de rendement par CMV et BlCMV.

Mots Clés: Virus de la mosaïque de la cornille Blackeye, Vigna unguiculata 


\section{INTRODUCTION}

Cowpea or Southernpea [Vigna unguiculata (L.) Walp.] is a nutritious annual legume and an important staple in many parts of the world (Quinn and Myers, 2002; Langyintuo et al., 2003). Since 2004, the area for cowpea production worldwide has increased by $34 \%$ to almost 12 million hectares in 2008 (FAO, 2008; 2010).

Viral diseases are a limiting factor in cowpea production worldwide. Hence, identifying sources of resistance is an important objective of cowpea breeding programmes (Ehlers and Hall, 1997; Singh et al., 2003). In 2004, the U.S.A. Vigna Crop Germplasm Committee (2004) revised its list of priority evaluation needs for cowpea to include resistance against important cowpea viruses. Developing disease resistant cowpea genotypes is also a major objective of the Bean/Cowpea Collaborative Research Support Programme funded by the U.S. Agency for International Development (Hall et al., 2003).

Two of the most common viruses affecting cowpea production in the United States are the cucumovirus, Cucumber mosaic virus (CMV), and the potyvirus, Blackeye cowpea mosaic virus (BlCMV). BICMV is regarded as a distinct strain of the Bean common mosaic virus (ICTV, 2010). The accession GC-86L-98 (PI-612607) is a germplasm line with resistance to $\mathrm{CMV}$ and to BlCMV that was released in 2001 (Gillaspie, 2002). However, few cultivars with CMV or BICMV resistance are currently available to growers worldwide. The cultivar, KnuckleHullVNR, a crowder-type of cowpea with resistance to BICMV and root-knot nematode, was released in 2002 by Fery et al. (2004). After a 3-year field testing period, this cultivar showed high resistance to BICMV and an average yield of $916 \mathrm{~kg} \mathrm{ha}^{-1}$ (Fery et al., 2004).

For years, seed of photoperiod-sensitive accessions in the U.S. Department of Agriculture (USDA) cowpea germplasm collection has been regenerated at the USDAARS facilities in Isabela, Puerto Rico (Gillaspie et al., 1999). Genetic diversity for tolerance to viral diseases has been observed by the authors during these regeneration cycles. In this study, tolerance is defined as the ability of a genotype to produce a good crop even when it is infected with a pathogen (Agrios, 2005).

The present study was conducted with the objective to determine yield potential and seed protein of various cowpea genotypes that have shown viral disease tolerance in unreplicated seed regeneration plots as an effort to identify materials that could be used by growers and/or breeders in cowpea improvement programmes.

\section{MATERIALS AND METHODS}

This study was conducted at the USDA-ARS Research Farm at Isabela, Puerto Rico. The Coto soil is a well-drained Oxisol (clayey, kaolinitic, isohyperthermic, Typic Hapludox). Relevant soil chemical properties in the evaluation plots during each year are presented in Table 1. The 25-year mean annual rainfall is $1649 \mathrm{~mm}$, and Class A pan evaporation is $1672 \mathrm{~mm}$. Mean monthly maximum and minimum temperatures are 29.8 and $19.9^{\circ} \mathrm{C}$.

Field experiments were established on 1 February 2007 and 18 September 2008 using plant introductions (PI's) 180014, 441917, 441919, and 612607 and the commercial cultivar Coronet. PI's 441919 and 612607 were included in the study as virus-resistant controls for CMV and BlCMV (Gillaspie, 2006). Cultivar Coronet was used as a susceptible control to both viruses (Gillaspie, 2002). PI 180014 was included as a high seed protein control

TABLE 1. Pre study soil characteristics at test plots in Isabela, $\mathrm{PR}$, measured to a depth of $20 \mathrm{~cm}$

\begin{tabular}{lrr}
\hline Soil characteristics & \multicolumn{2}{c}{ Year } \\
\cline { 2 - 3 } & 2007 & 2008 \\
\hline pH in water & 5.8 & 5.8 \\
Ammonium nitrogen $\left(\mathrm{mg} \mathrm{kg}^{-1}\right)$ & 9.5 & 9.5 \\
Nitrate nitrogen $\left(\mathrm{mg} \mathrm{kg}^{-1}\right)$ & 19 & 19 \\
Organic C $(\%)$ & 0.94 & 1.15 \\
$\mathrm{P}\left(\mathrm{mg} \mathrm{kg}^{-1}\right)$ & 53 & 52 \\
$\mathrm{~K}\left(\mathrm{cmol} \mathrm{kg}^{-1}\right)$ & 0.87 & 0.71 \\
$\mathrm{Ca}\left(\mathrm{cmol} \mathrm{kg}^{-1}\right)$ & 1.89 & 2.03 \\
$\mathrm{Mg}\left(\mathrm{cmol} \mathrm{kg}^{-1}\right)$ & 0.72 & 0.68 \\
\hline
\end{tabular}


(Goenaga et al., 2008). Phenotypic descriptors and origin of genotype are shown in Table 2.

The experiments were planted in a randomised complete block design with three replications. Because of the prostrate growth habit of some genotypes, experimental plots consisted of two 3-m rows spaced $3.6 \mathrm{~m}$ apart. Seedlings were thinned to an in-row spacing of $15 \mathrm{~cm}$. Each experimental plot was surrounded by rows of the virus-susceptible cultivar Coronet which served as the source of the viruses' inoculum (i.e., spreader plants). On 27 February 2007 and 14 October 2008, all spreader-row plants were mechanically inoculated with leaf tissue extracts obtained from symptomatic plants of the cultivar Coronet. This tissue was previously determined to be infected with BICMV and CMV by the direct antigen-coated enzyme-linked immonosorbent assay (DAC-ELISA) as described by Gillaspie et al. (1995).

Inoculum was prepared by macerating excised trifoliate leaves of the cultivar Coronet in $1 \%$ potassium phosphate buffer, $\mathrm{pH} 7.2(1 \mathrm{~g}$ fresh tissue with $10 \mathrm{~mL}$ buffer). Spreader plants were then inoculated by dusting 320-grit Carborundum onto two trifoliate leaves and applying the inoculum with a cotton swab. Inoculation of spreader plants was repeated 2 weeks after the first inoculation to reduce the possibility of plants escaping infection.

At about 65 days after planting, leaf samples from spreader plants were taken from eight random plants per row and sent by overnight mail to the Plant Genetics Resources Conservation Unit, Griffin, Georgia, USA, for virus testing by DAC-ELISA. This date was close to the midbloom period. In addition to BICMV and $\mathrm{CMV}$, testing for the bromovirus Cowpea chlorotic mottle virus (CCMV), which is commonly found in Isabela, was also conducted. Experimental plants were not inoculated because of the possibility of virus resistance being the result of resistance to insects that transmit the viruses (e.g. aphids, bean leaf beetle). Fertilisation was provided 1 month after planting using a $16 \mathrm{~N}-1.7 \mathrm{P}-3.3 \mathrm{~K}$ commercial mixture at a rate of $132 \mathrm{~kg} \mathrm{ha}^{-1}$. Plants were drip irrigated as necessary. Insect control was carried out with Malathion 57 EC (Loveland Products Inc., Greeley, CO) at recommended rates

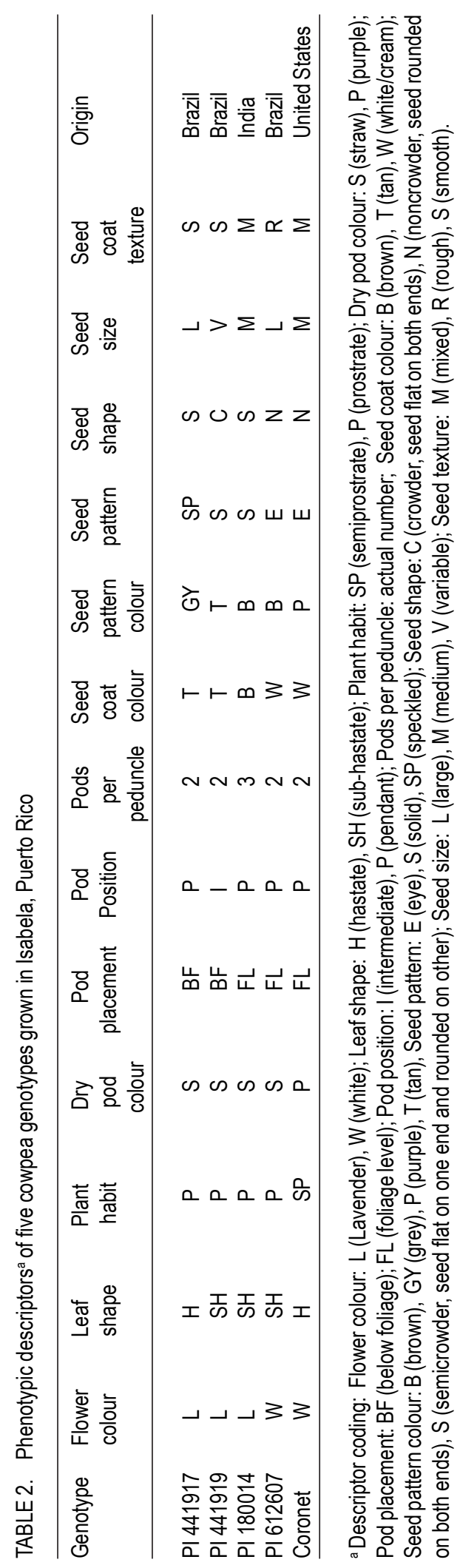


only during the pod filling period to prevent damage by pod worms.

Midbloom and maturity were determined as the number of days after planting at which $50 \%$ of plants flowered and the first dry pod appeared, respectively. Plant height was measured at midbloom with a ruler at midrow. Pods were harvested by hand as they matured, dried at 38 ${ }^{\circ} \mathrm{C}, 25 \%$ relative humidity, and shelled. Pod length was determined by averaging the length of 10 mature pods from five plants selected randomly from each plot.

Random 100-seed samples from each experimental unit were weighed to determine average seed weight. Seed N was determined using the micro-Kjeldahl procedure and multiplied by the factor 6.25 to obtain percent seed protein (AOAC, 2000). Analysis of variance was carried out using the GLM procedure of SAS (release 9.1 for Windows; SAS Institute, Cary, NC). After significant F tests at $P<0.05$, mean separation was performed using the least significant difference.

\section{RESULTS AND DISCUSSION}

Combined analysis of variance showed statistically significant $(\mathrm{P}<0.05)$ genotype and year effects on most parameters measured in the study (Table 3). The genotype $\mathrm{x}$ year interaction was not significant $(\mathrm{P}>0.05)$ for grain yield and other parameters; therefore these data were averaged and analysed over years.

ELISA results showed that all plots of the virus susceptible control 'Coronet' were infected with CMV, CCMV and BlCMV in 2007. In 2008, all 'Coronet' plots were infected with BICMV and 2 out of 3 plots were infected with CMV; infection with CCMV in 2008 was minimal (Table 4). ELISA results for 'Coronet' spreader plants conducted on 7 March 2007 and 20 October 2008 showed the presence of the three viruses (data not shown). This suggests that virus infection of experimental plants occurred via insect transmission. Incidence of BlCMV in all genotypes was higher in 2008 than in 2007.

ELISA readings for leaf samples of genotype 441917 demonstrated no CMV and BlCMV infection in 2007, no CMV or CCMV infection in 2008 and, relative low absorbance values for BlCMV in 2008 (Table 4). This genotype had the highest grain yield among genotypes, except for the virus resistant control PI 612607, which was not significantly different (Table 3 ). As compared to genotypes 180014, 441919 and cultivar Coronet, grain yield of PI 441917 was 57, 205 and $136 \%$ higher, respectively. These results confirm previous studies which showed that PI 441917 was an excellent yielder even when plants were infected with BlCMV or CMV (Goenaga et al., 2008).

TABLE 3. Yield components and other parametres of five cowpea genotypes in field experiments conducted at Isabela, Puerto Rico

\begin{tabular}{|c|c|c|c|c|c|c|c|}
\hline Genotype & $\begin{array}{l}\text { Grain yield } \\
\left(\mathrm{kg} \mathrm{ha}^{-1}\right)\end{array}$ & $\begin{array}{c}\text { Seed protein } \\
(\%)\end{array}$ & $\begin{array}{l}100 \text {-seed } \\
\text { weight }(\mathrm{g})\end{array}$ & $\begin{array}{l}\text { Midbloom } \\
\text { (days) }\end{array}$ & $\begin{array}{r}\text { Maturity } \\
\text { (days) }\end{array}$ & $\begin{array}{c}\text { Plant } \\
\text { height }(\mathrm{cm})\end{array}$ & $\begin{array}{l}\text { Pod length } \\
(\mathrm{cm})\end{array}$ \\
\hline PI 441917 & 3682.8 & 22.8 & 20.2 & 48.5 & 66.3 & 48.0 & 23.7 \\
\hline PI 612607 & 2774.4 & 25.3 & 18.9 & 60.5 & 79.0 & 44.2 & 14.6 \\
\hline PI 180014 & 2348.4 & 26.1 & 8.5 & 48.8 & 63.7 & 49.8 & 14.2 \\
\hline PI 441919 & 1208.8 & 24.7 & 19.7 & 58.5 & 74.0 & 44.5 & 20.7 \\
\hline Coronet & 1556.6 & 24.2 & 14.3 & 42.7 & 59.5 & 53.5 & 17.5 \\
\hline Average & 2314.2 & 24.6 & 16.3 & 51.8 & 68.5 & 48.0 & 18.1 \\
\hline LSD $(0.05)^{a}$ & 1095.2 & 1.4 & 1.6 & 2.8 & 1.8 & 3.7 & 1.1 \\
\hline Genotype (G) & ** & $* *$ & $* * *$ & $* * *$ & $* * *$ & $* * *$ & $* * *$ \\
\hline Year $(Y)$ & * & $* *$ & NS & * & $* *$ & * & NS \\
\hline$G \times Y$ & NS & NS & * & $* * *$ & $* * *$ & NS & NS \\
\hline
\end{tabular}

a Least significant difference at $P=0.05$

NS, ,"w, ", * Nonsignificant or significant at $P$ d" $0.001,0.01$, or 0.05 , respectively 
TABLE 4. Absorbance readings for Cucumber mosaic virus (CMV), Cowpea chlorotic mottle virus (CCMV), and Blackeye cowpea mosaic virus (BIMCV) in cowpea genotypes determined by direct antigen coating-enzyme linked immunosorbent essay in 2007 and 2008 from samples collected at approximately mid-bloom

\begin{tabular}{|c|c|c|c|c|c|c|c|}
\hline \multirow[t]{3}{*}{ Genotype } & \multirow[t]{3}{*}{ Replication } & \multicolumn{6}{|c|}{ Year } \\
\hline & & \multicolumn{3}{|c|}{2007} & \multicolumn{3}{|c|}{2008} \\
\hline & & CMV & CCMV & BICMV & CMV & CCMV & BICMV \\
\hline PI 441917 & 1 & $0^{\mathrm{b}}$ & 0.2590 & 0 & 0 & 0 & 0.3465 \\
\hline PI 612607a & 0 & 0 & 0 & 0 & 0 & 0.5260 & \\
\hline Pi 180014 & & 0 & 0.3135 & 0.6735 & 0 & 0 & 1.2350 \\
\hline PI 441919 & & 0 & 0 & 0 & 0 & 0 & 0.8825 \\
\hline Coronet & & 0.2040 & 1.5125 & 0.1560 & 1.1365 & 0 & 0.9640 \\
\hline PI 441917 & 2 & 0 & 0 & 0 & 0 & 0 & 0.3955 \\
\hline PI 612607a & & 0 & 0 & 0 & 0 & 0 & 0.3695 \\
\hline PI 180014 & & 0 & 0 & 0.4450 & 0 & 0 & 1.4435 \\
\hline PI 441919 & & 0 & 0 & 0 & 0 & 0 & 0.6185 \\
\hline Coronet & & 0.3455 & 1.7890 & 0.1730 & 0.2880 & 0 & 0.5990 \\
\hline PI 441917 & 3 & 0 & 0 & 0 & 0 & 0 & 0.3485 \\
\hline PI 612607a & & 0 & 0.1075 & 0 & 0 & 0 & 0.5185 \\
\hline PI 180014 & & 0.1450 & 0.3230 & 0.5915 & 0 & 0 & 1.3740 \\
\hline PI 441919 & & 0 & 0 & 0 & 0 & 0 & 1.0740 \\
\hline Coronet & & 0.1355 & 1.2765 & 0.2020 & 0 & 0.1100 & 0.7510 \\
\hline
\end{tabular}

${ }^{a}$ Cowpea genotype reported by Gillaspie (2002) to have CMV and BICMV resistance. ${ }^{\mathrm{b}}$ Zero absorbance denotes absence of virus

All plots of PI 61207 were infected with BlCMV (Table 4) which contrasts the results obtained by Gillaspie (2002) describing this genotype as resistant to this virus. PI 180014 had high absorbance readings for CCMV and BlCMV in 2007 and for BlCMV in 2008, but grain yield was not significantly different than that for PI612607 (Tables 3 and 4).

PI 441919 was only affected by BlCMV in 2008 but grain yield was low and not significantly different than that for the susceptible control 'Coronet'. The grain yield obtained by PI 441917 in this study (Table 3) was more than twice the mean yield $(1424 \mathrm{~kg}$ $\mathrm{ha}^{-1}$ ) of 25 improved, early-maturing varieties grown with good management in West Africa (Singh et al., 2003).

Genotype 441917 had a significantly lower seed protein concentration than other genotypes (Table 3). As compared to the high-seed protein control, PI 180014, PI 441917 had a $12.6 \%$ lower seed protein concentration. An inverse relationship between seed yield and seed protein concentration was established for other legume crops (Cober and Voldeng, 2000; de Mello Filho et al., 2004).

Genotype 441917 had the highest 100-seed weight, although it did not differ significantly from PI's 441919 and 612607 (Table 3). Midbloom mean for all genotypes was $51.8 \mathrm{~d}$ (Table 3). However, cultivar Coronet took significantly shorter time to attain midbloom and maturity than other genotypes. Cultivar Coronet and PI 180014 were significantly taller genotypes $(51.6 \mathrm{~cm})$, but there was no significant difference in plant height between PI's 180014 and 441917. Among the genotypes used in the study, PI 441917 produced significantly longer pods, averaging $23.7 \mathrm{~cm}$ in length (Table 3).

In conclusion, PI 441917 outperforms all other genotypes for grain yield when it is grown under virus pressure, particularly BlCMV. This PI should be useful to growers and to breeding programmes seeking to control yield losses caused by viruses, particularly BICMV and CMV. 
Seed of PI 441917 is deposited in the U.S. National Plant Germplasm System where it is available for research purposes, including development and commercialisation of new varieties/cultivars. A limited quantity of seed of PI 441917 may be obtained by writing to orders@ ars-grin.gov or to the principal author.

\section{ACKNOWLEDGEMENT}

The authors thank Angel Marrero, Tomás Miranda, Pablo Ríos, James Chalkley and Dave Pinnow for their excellent field and laboratory assistance.

\section{REFERENCES}

Agrios, G.N. 2005. Plant pathology. Elsevier Academic Press, Boston, MA. pp. 134-139.

Association of Official Analytical Chemists (AOAC). 2000. Official method of analysis of AOAC International. Vol. 1: Agricultural chemicals; contaminants; drugs, p. 29-30C. In: Horwitz, W. (Ed.). AOAC official method 2001.11 protein (crude) in animal feed, forage (plant tissue), grain, and oil seeds AOAC International, Gaithersburg, MD.

Cober, E.R. and Voldeng, H.D. 2000. Developing high-protein, high-yield soybean populations and lines. Crop Science 40:39-42.

de Mello Filho, O.L., Sigueyuki Sediyama, C., Alves Moreira, M., Silva Reis, M., Massoni, G.A. and Piovesan, N.D. 2004. Grain yield and seed quality of soybean selected for high protein content. Pesquisa Agropecudria Brasileira 29:445-450.

Ehlers, J.D. and Hall, A.E. 1997. Cowpea (Vigna unguiculata L. Walp). Field Crops Research 53:187-204.

Fery, R.L., Thies, J.A. and Gillaspie, A.G., Jr. 2004. 'KnuckleHull-VNR', a crowder-type southernpea resistant to Blackeye cowpea mosaic virus and root-knot nematode. HortScience 39:183-184.

Food and Agriculture Organisation (FAO). 2008. FAOSTAT. 2010. http://faostat.fao.org/site/ 567/DesktopDefault.aspx?pageID=567. Accessed 1 September 2010.
Gillaspie, A.G. Jr. 2002. Registration of GC-86L98 cowpea germplasm resistant to Cucumber mosaic virus and Blackeye cowpea mosaic virus. Crop Science 42:1385.

Gillaspie, A.G. Jr. 2006. New method for screening cowpea germplasm for resistance to Cucumber mosaic virus. Plant Disease 90:611-614.

Gillaspie, A.G., Jr., Goenaga, R., Torres, S. and Peregrine, E. 1999. Identification of suitable seed regeneration sites for photoperiod-sensitive cowpea germplasm. Crop Science 39:1513-1515.

Gillaspie, A.G. Jr., Hopkins, M.S., Pinnow, D.L. and Hampton, R.O. 1995. Seedborne viruses in preintroduction cowpea seed lots and establishment of virus-free accessions. Plant Disease 79:388-391.

Goenaga, R., Gillaspie, A.G. and Quiles, A. 2008. Assessing yield potential of cowpea genotypes grown under virus pressure. HortScience 43:673-676.

Hall, A.E., Cisse, N., Thiaw, S., Elawad, H.O.A., Ehlers, J.D., Ismail, A.M., Fery, R.L., Roberts, P.A., Kitch, L.W., Murdock, L.L., Boukar, O., Phillips, R.D. and McWatters, K.H. 2003. Development of cowpea cultivars and germplasm by the Bean/Cowpea CRSP. Field Crops Research 82:103-134.

International Committee on Taxonomy of Viruses (ICTV). 2010. ICTVdB index of viruses. http://www.ictvonline.org/virus taxonomy.asp?version=2009. Accessed 1 September 2010.

Langyintuo, A.S., Lowenberg-DeBoer, J., Faye, M., Lambert, D., Ibro, G., Moussa, B., Kergna, A., Kushwaha, S., Musa, S. and Ntoukam, G. 2003. Cowpea supply and demand in West and Central Africa. Field Crops Research 82:215-231.

Quinn, J. and Myers, R. 2002. Cowpea: A versatile legume for hot, dry conditions. http://www.jeffersoninstitute.org/pubs/ cowpea_guide.pdf. Accessed 1 September 2010.

Singh, B.B., Ajeigbe, H.A., Tarawali, S.A., Fernandez-Rivera, S. and Abubakar, M. 2003. Improving the production and utilization of 
cowpea as food and fodder. Field Crops Research 84:169-177.

Vigna Crop Germplasm Committee. 2004. Vigna germplasm: current status and future needs. http://www.ars-grin.gov/npgs/cgc_reports/ vignarpt2004.pdf. Accessed 1 September 2010. 